\title{
Evaluation of green extraction methods on the chemical and nutritional aspects of roselle seed (Hibiscus sabdariffa L.) oil ${ }^{\text {i }}$
}

\author{
Moahamed A. Naeem ${ }^{1}$, Hamdy A. Zahran ${ }^{2}$ and Minar M.M. Hassanein ${ }^{2, *}$ \\ ${ }^{1}$ Fellow Nutrition and Food science of Ain Shams University Specialized Hospital, Ain Shams University, Cairo, Egypt \\ ${ }^{2}$ Fats and Oils Department, National Research Centre, Dokki 12622, Cairo, Egypt
}

Received 8 April 2019 - Accepted 13 June 2019

\begin{abstract}
Roselle is one of the valuable plants grown in some regions of Egypt, which is used to make juices or as natural food color additive. Roselle seeds are waste, which can be used as a source of nontraditional oil, nutritious or functional compound. The evaluation of green extraction methods including supercritical $\mathrm{CO}_{2}\left(\mathrm{SC}-\mathrm{CO}_{2}\right)$, screw, hydraulic press comparing to traditional method on oil yield, total phenolics, antioxidant activity (DPPH) and oxidative stability of roselle seeds oil were investigated. Fatty acid composition and tocopherol of the oil were also determined. The results showed that the roselle seeds oil extracted by solvent gave the highest oil content and extraction rate (17.98 and $98.34 \%$, respectively) and the lowest peroxide and acid value. $\mathrm{SC}-\mathrm{CO}_{2}$ gave the higher content of alpha, gamma, and delta tocopherol comparing to the other extraction methods. Fatty acid showed that linoleic acid, an essential fatty acid, was dominant followed by oleic and palmitic acids. These fatty acids were higher amounts in oil extracted by $\mathrm{SC}-\mathrm{CO}_{2}$, followed by cold-press comparing to solvent extraction. The maximum stability ( $\left.20 \mathrm{~h}\right)$, higher TPC $\left(22.18 \mathrm{mg} \mathrm{GAE} / \mathrm{g}\right.$ ) and antioxidant activity (DPPH, 65.15) were observed in oil extracted by $\mathrm{SC}-\mathrm{CO}_{2}$ followed by hydraulic-press, solvent extraction and finally screw-press. The results revealed that $\mathrm{SC}-\mathrm{CO}_{2}$ method is more efficient in determination of total tocopherol, oxidative stability, TPC and radical scavenging activity than the other extraction methods. Cold press extraction methods gave higher oil yield than $\mathrm{SC}-\mathrm{CO}_{2}$ and more economically than other methods.
\end{abstract}

Keywords: roselle seed oil / green extraction methods / oxidative stability / non-traditional oil / antioxidant activity

Résumé - Évaluation de méthodes d'extraction vertes sur les caractéristiques chimiques et nutritionnelles de l'huile de graines d'Hibiscus (Hibiscus sabdariffa L.). L'hibiscus constitue l'une des plantes d'intérêt cultivées dans certaines régions d'Égypte, utilisée pour fabriquer des jus ou comme source de colorant alimentaire. Les graines d'hibiscus étant inutilisées dans ces filières, elles peuvent être employées comme source d'huile non traditionnelle, de composés nutritionnels ou fonctionnels. Les méthodes d'extraction vertes, parmi lesquelles l'extraction au $\mathrm{CO}_{2}$ supercritique $\left(\mathrm{SC}-\mathrm{CO}_{2}\right)$, la presse à vis et la presse hydraulique, ont été comparées à la méthode traditionnelle en termes de rendement en huile, de teneurs en composés phénoliques totaux, d'activité anti-oxydante (DPPH) et de stabilité à l'oxydation de l'huile de graines d'hibiscus. Les résultats montrent que l'huile de graines d'hibiscus extraite par solvant donne les plus grands rendement et taux d'extraction (17,98 et 98,34\%, respectivement), et les plus faibles indices d'acide et de peroxyde. L'extraction au $\mathrm{SC}-\mathrm{CO}_{2}$ conduit aux teneurs les plus élevées en tocophérols alpha, gamma et delta par rapport aux autres méthodes d'extraction. En termes de profil en acides gras, l'acide linoléique, un acide gras essentiel, se révèle prédominant, suivi par les acides oléique et palmitique. Ces acides gras présentent des teneurs plus élevées dans l'huile extraite par $\mathrm{SC}-\mathrm{CO}_{2}$, puis dans l'huile produite par pression à froid, par rapport à l'extraction par solvant. La stabilité maximale $(20 \mathrm{~h})$, la plus haute teneur en TPC $(22,18 \pm 1,13 \mathrm{mgEAG} / \mathrm{g})$, et l'activité anti-oxydante la plus élevée (DPPH, $65,15 \pm 2,08 \%)$ sont observées dans l'huile extraite par $\mathrm{SC}_{-} \mathrm{CO}_{2}$ suivie par la presse hydraulique, l'extraction par solvant et enfin la presse à vis. Les résultats révèlent ainsi que l'extraction au $\mathrm{SC}-\mathrm{CO}_{2}$

\footnotetext{
Contribution to the Topical Issue "Lipids and Health / Lipides et

santé"

*Correspondence: minarmahmoud@gmail.com
} 
constitue la méthode la plus performante quant aux teneurs en tocophérols totaux, la stabilité oxydative, la teneur en TPC et la neutralisation des radicaux par rapport aux autres méthodes d'extraction. Les méthodes d'extraction à froid conduisent quant à elles à des rendements en huile plus élevés que l'extraction SC- $\mathrm{CO}_{2}$ et s'avèrent plus économiques que les autres méthodes.

Mots clés : huile de graines d'hibiscus / méthodes d'extraction vertes / stabilité oxydative / huile non traditionnelle / activité antioxydante

\section{Introduction}

Roselle (Hibiscus sabdariffa L.) seeds are the waste that is left behind during processing of roselle, also known as hibiscus, for juices or other roselle-related products. Disposal of wastes is highly undesirable both economically and environmentally. Roselle seeds are also a good source of dietary fibers and proteins that have great promise as a feed resource for livestock and value-added nutritional foods like defatted seed meal, protein concentrates from defatted seed, seed cake etc. (Atta and Imaizumi, 2002; Dhar et al., 2015).

Functional lipid components that are likely present in roselle seed oil include phytosterols and tocopherols which have therapeutic functions in preventing cardiovascular disease and types of cancer. (Nyam et al., 2009; Hassanien et al., 2014). Roselle seeds contain high levels of phytosterol, which have been associated with lowering total cholesterol and anti-carcinogenic effects in both animal and human studies. $\beta$-sitosterol, a phytosterol presence in roselle seeds, has secured an important place in the realm of health supplements with extensive scientific support for its prophylactic and therapeutic use for various physical ailments like arteriosclerosis, benign prostate cancer, and colon cancer (Nair et al., 2006; Yokota et al., 2006; Abdel-Razek et al., 2011; Hassanien et al., 2014; Rudzińska et al., 2016).

Roselle seed contains about $20 \%$ oil and is considered to have high nutritional value and health-promoting properties due to the presence of natural balance between saturated: monounsaturated: polyunsaturated fatty acids (Abdel-Razek et al., 2017; Al-Okbi et al., 2017). Ismail et al. (2008) and Naeem et al. (2017) found that roselle seeds contain reasonable amounts of protein, crude fiber, and oil, as well as carbohydrate $\left(146,212,146\right.$ and $356 \mathrm{~g} \mathrm{~kg}^{-1}$ by weight respectively).

Generally, the methods of extraction of seed oils are an effective factor in the properties of oils. Solvent extraction, for example, is insufficient in selectivity and needs excessive heat, which could cause the degradation of the desired components (Pokorny et al., 2001; Aniołowska et al., 2016; Rudzińska et al., 2018). The cold press (hydraulic and screwpress) extraction is the method for oil extraction. It involves no heat and/or chemicals and this is preferred by consumers concerned about natural and safe food (Kiralan et al., 2014). However, this method affords low yields (Soto et al., 2007), and the residual meal contains 10 to $12 \%$ oil content, which can eventually limit its uses in industries processing food (Zuniga et al., 2003). Supercritical fluid extraction (SFE) is currently a technique among others used to extract plant oils and offers some favorable features over the traditional techniques that have been used in the oil extraction (Akanda et al., 2012).
The aim of this work is studying the effect of green extraction method (supercritical $\mathrm{CO}_{2}$ and cold-press methods [hydraulic and screw press]) on major and minor components of roselle seed oil (RSO) comparing to traditional one (solvent extraction). In addition, comparing the physicochemical and nutritional characteristics of RSO extracted by green and traditional methods with regard to the oil quality properties, antioxidant activity, and the oxidative stability of the extracted oil.

\section{Materials and methods}

\subsection{Materials}

Roselle (Hibiscus sabdariffa L.) seeds were purchased from the local market in June 2018 from Aswan, Egypt. All reagents and solvents used in this study were analytical grade.

\subsection{Methods}

\subsubsection{Roselle seeds pretreatment}

The roselle seeds (RS's) were kept at $60{ }^{\circ} \mathrm{C}$ for one hour in oven, to facilitate the extraction from seeds (Elabd et al., 2017).

\subsubsection{Extraction method}

\subsubsection{Supercritical $\mathrm{CO}_{2}$ extraction}

The extraction process was carried out on laboratory scale high-pressure extraction plant (HPEP, NOVA-Swiss, Effretikon, Switzerland) according to the method described by Cvjetko et al. (2012). The ground sample of $300 \mathrm{~g}$ was placed into the extractor vessel. To fill up the extraction vessel, diatomaceous earth (kieselguhr) was used as inert material. The extracted oil was collected into a previously weighed glass vials. A balance (precision of $\pm 0.0001 \mathrm{~g}$ ) was used to weigh the extracted oil at regular time intervals. A mass flow rate of $\mathrm{CO}_{2}$, expressed under normal conditions, was $0.194 \mathrm{~kg} \mathrm{~h}^{-1}$, low enough to ensure the saturation of supercritical $\mathrm{CO}_{2}(\mathrm{SC}-$ $\mathrm{CO}_{2}$ ) with the solute. The investigated values of pressure varied from 20 to $30 \mathrm{MPa}$, temperature varied from 40 and $60^{\circ} \mathrm{C}$ during the extraction time up to $4 \mathrm{~h}$. Separation conditions were $1.5 \mathrm{MPa}$ and $25^{\circ} \mathrm{C}$. The obtained RSO was placed into glass vials, sealed and stored at $-18^{\circ} \mathrm{C}$ until analysis.

\subsubsection{Hydraulic-press extraction}

Roselle seed oil (RSO) was extracted by hydraulic cold pressing machine at room temperature using pressure at $10 \mathrm{MPa}$. Then, extracted oil was filtered using Whatman filter 
No. 1, afterward was centrifuged at $3500 \mathrm{rpm}$ for $20 \mathrm{~min}$ in order to separate those components settled during storage.

\subsubsection{Screw-press extraction}

A continuous process (screw-press) was used to extract oil from RS's. The extraction temperature was about $45^{\circ} \mathrm{C}$, at a rotational speed of $30 \mathrm{rpm}$. After pressing the oils were collected, and stored at $-18^{\circ} \mathrm{C}$ until analysis.

\subsubsection{Solvent extraction}

The oil extraction from ground RS's was performed in Fats and Oils Department National Research Centre, Cairo, Egypt according to the Soxhlet extraction method. The n-hexane was used as extraction solvent at a ratio of 1:10, a sample to solvent (Bhatnagar and Krishna 2013).

\subsubsection{Determination of physicochemical properties}

\subsubsection{Oil content (\%) and extraction rate}

The percentage of oil content in RS's was calculated according to the method described by AOCS, Firestone (2009), using the following equation:

$$
\% \text { of extracted oil }=\left[W_{O} / W_{S}\right] * 100,
$$

where: $W_{O}$ is a weight of obtained oil in $\mathrm{g}, W_{S}$ is a weight of seeds in $\mathrm{g}$.

\subsubsection{The oil recovery efficiency (ORE)}

The oil recovery efficiency (ORE) is the ratio of actual oil produced by certain method such as $\mathrm{SC}-\mathrm{CO}_{2}$ or hydraulicpress or screw-press to the oil contained in the RS recovered from solvent extraction (n-hexane) by Soxhlet method according to the following equation (Donough et al., 2013):

$$
\operatorname{ORE}(\%)=\left[P_{1} / P_{0}\right] * 100,
$$

where: $P_{1}$ is the weight of oil extracted by certain method; $P_{0}$ is the weight of oil recovered by solvent extraction method (Soxhlet).

\subsubsection{Physicochemical properties}

Physicochemical analyses of RSO samples such as refractive index, peroxide value, free fatty acid $\%$, saponification value, specific gravity, and iodine value were accomplished based on Official Methods of AOCS, Firestone (2009).

\subsubsection{Fatty acid composition (GC-MS)}

Methyl esters of fatty acids (FAME) were prepared according to Official Methods and Recommended Practices of the AOCS, Firestone (2009). Diluted FAME was separated on an HP 5890 series II (Hewlett Packard, HP, Palo Alto, USA) equipped with an Innowax capillary column (30 m, $0.20 \mathrm{~mm}$ ) and flame ionization detector (FID). Hydrogen was used as the carrier gas at a flow rate of $1.5 \mathrm{~mL} \mathrm{~min}^{-1}$. The column temperature was isotherm $210^{\circ} \mathrm{C}$. Detector and injector temperatures were set at $240^{\circ} \mathrm{C}$. Fatty acids were identified by comparison of the retention times with authentic standards and the results were reported as weight percentages after integration and calculation using Chem. Station (Agilent Technologies).

\subsubsection{Calculated oxidizability value (Cox)}

The Cox value of the oils was calculated from the values of the fatty acid percent, according to Fatemi and Hammond (1980) using the following equation:

$$
\begin{aligned}
\text { Cox value } & =\left[1 *\left(\mathrm{C}_{18: 1}\right)+10.3 *\left(\mathrm{C}_{18: 2}\right)+21.6\right. \\
& \left.*\left(\mathrm{C}_{18: 3}\right)\right] / 100 .
\end{aligned}
$$

\subsubsection{Determination of RSO tocopherols}

RSO Samples were saponified according to Lee et al. (2012). HPLC analysis was carried out using Agilent Technologies 1100 series liquid chromatograph equipped with an auto-sampler and a diode-array detector. The analytical column was a LiChrospher 5 RP Select B $(250 \times 4.0 \mathrm{~mm}$; $5 \mu \mathrm{m}$ ) with a C18 guard column (Phenomenex, Torrance, CA). The mobile phase consisted of acetonitrile (solvent $\mathrm{A}$ ) and methanol (solvent B). The flow rate was kept at $1.0 \mathrm{~mL} / \mathrm{min}$ for a total run time of $30 \mathrm{~min}$ and the gradient program was as follows: $100 \%$ B to $85 \%$ B in $30 \mathrm{~min}, 85 \%$ B to $50 \%$ B in $20 \mathrm{~min}, 50 \% \mathrm{~B}$ to $0 \% \mathrm{~B}$ in $5 \mathrm{~min}$ and $0 \% \mathrm{~B}$ to $100 \% \mathrm{~B}$ in $5 \mathrm{~min}$. The injection volume was $50 \mu \mathrm{l}$ and peaks were monitored simultaneously at 280 and $320 \mathrm{~nm}$ for the benzoic acid and cinnamic acid derivatives, respectively. All samples were filtered through a $0.45 \mu \mathrm{m}$ Acrodisc syringe filter (Gelman Laboratory, MI) before injection. Peaks were identified by congruent retention times and UV spectra and compared with those of the standards.

\subsubsection{Total phenolic content (TPC)}

Folin-Ciocalteu method was used for determination TPC according to the reported method by Gutfinger (1981). RSO $(2.5 \mathrm{~g})$ was dissolved in $5 \mathrm{~mL}$ hexane and extraction was carried out by methanol/water solution $(80: 20, \mathrm{v} / \mathrm{v})$. The aqueous phase was collected by centrifugation at $3500 \mathrm{rpm}$ for $5 \mathrm{~min}$, followed by vacuum drying at room temperature. The dried sample was dehydrated in $5 \mathrm{~mL}$ of the methanol solution, mixed with $2.5 \mathrm{~mL}$ of Folin reagent and $10 \mathrm{~mL}$ of sodium carbonate solution in $50 \mathrm{ml}$ volumetric flask, and was adjusted to volume with deionized water. The absorbance was measured at $765 \mathrm{~nm}$ after $30 \mathrm{~min}$. Gallic acid was used for calibration and the results were expressed as mg gallic acid equivalent (GAE) per $100 \mathrm{~g}$ of oil samples.

\subsubsection{Radicals scavenging activity}

The radical scavenging ability of the extracts was determined using the stable DPPH free radical (2,2diphenyl-1-picrylhydrazyl) according to Wong et al. (2016). The methanol solution prepared previously $(0.3 \mathrm{~mL})$ was mixed with $2.7 \mathrm{~mL}$ of a freshly prepared DPPH solution $\left(6 \times 10^{-5} \mathrm{M}\right.$ in $95 \%$ methanol $)$. The mixture was shaken vigorously and left at room temperature for $60 \mathrm{~min}$ in the dark until stable absorbance values were obtained. The control contained methanol in place of the sample. The change in the 
M.A. Naeem et al.: OCL 2019, 26, 33

Table 1. Effect of green and traditional extraction methods on physico-chemical properties of RSO.

\begin{tabular}{|c|c|c|c|c|}
\hline Characteristics & \multicolumn{4}{|c|}{ Extraction methods } \\
\hline Oil content $(\%)$ & $8.75 \pm 1.04^{\mathrm{c}}$ & $9.35 \pm 1.13^{\mathrm{c}}$ & $12.17 \pm 0.89^{\mathrm{b}}$ & $18.98 \pm 1.54^{\mathrm{a}}$ \\
\hline Free Fatty Acid (as \% oleic acid) & $0.30 \pm 0.05^{\mathrm{c}}$ & $0.61 \pm 0.11^{\mathrm{bc}}$ & $0.71 \pm 0.15^{\mathrm{b}}$ & $2.41 \pm 0.37^{\mathrm{a}}$ \\
\hline Iodine Value (g/100 g) & $97.76 \pm 0.35^{\mathrm{a}}$ & $94.50 \pm 1.24^{\mathrm{b}}$ & $93.62 \pm 0.95^{\mathrm{b}}$ & $93.41 \pm 1.35^{\mathrm{b}}$ \\
\hline Refractive Index & $1.4504 \pm 0.0001^{\mathrm{b}}$ & $1.4494 \pm 0.0003^{\mathrm{b}}$ & $1.4500 \pm 0.0002^{\mathrm{b}}$ & $1.4562 \pm 0.0001^{\mathrm{a}}$ \\
\hline Saponification value $(\mathrm{mg} / \mathrm{g})$ & $191.04 \pm 1.13^{\mathrm{b}}$ & $193.65 \pm 2.50^{\mathrm{a}}$ & $193.91 \pm 1.59^{\mathrm{a}}$ & $190.87 \pm 3.47^{\mathrm{b}}$ \\
\hline
\end{tabular}

The values were expressed as mean \pm standard deviation of three determinations.

Values in the rows with different letters $(\mathrm{a}-\mathrm{d})$ are significantly different $(p<0.05)$. The same letters at the same column are not significant $(p<0.05)$.

absorbance of the extracts was measured at $517 \mathrm{~nm}$ using a spectrophotometer. The percentage inhibition of the DPPH radicals was calculated using the equation below.

$$
\text { DPPH scavenging activity }(\%)=[(A c-A s) / A c] \times 100,
$$

where $A c$ and $A s$ is the absorbance of the blank (control) and samples, respectively.

\subsubsection{Oxidative stability index (OSI)}

For determination of oxidative stability of oils, AOCS Official Method Cd 12b-92 (AOCS, 1997) was used. The test was performed on an automated Metrohm Rancimat model 743 (Herisau, Switzerland) at $110 \pm 0.1^{\circ} \mathrm{C}$ and an airflow of $20 \mathrm{~L} \mathrm{~h}^{-1}$ to determine the induction period (IP) of the oil samples.

\subsection{Statistical analysis}

All measurements were replicated three times. Statistical analyses were conducted using SPSS program version 20 for windows. Significant differences among samples were analyzed by using ANOVA, Duncan-post hoc test at a level of $p \leq 0.05$.

\section{Results and discussion}

\subsection{Physiochemical properties of roselle seed oil (RSO)}

The results of oil contents, extraction rate, refractive index, specific gravity, free fatty acid, peroxide value, iodine value and a saponification value of RSO extracted by different methods are presented in Table 1. The results obtained showed that RS is considered as a valuable source of oil content $(\%)$ ranged from 8.75 to $18.98 \%$. According to the results which are shown in Table 1 , it was found that the solvent extraction gave the highest oil yield while screw-press gave the higher oil recovery efficiency (ORE) (Fig. 1). This result agreed with Al-Okbi et al. (2017), which found that the oil content obtained by solvent extraction was $20 \%$.

Determination of free fatty acid (FFA) is usually considered to be one of the main parameters to reflect the

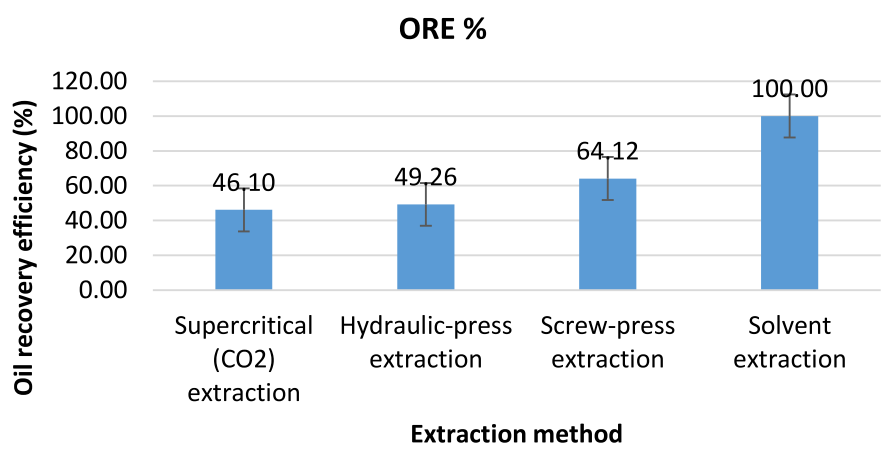

Fig. 1. Oil recovery efficiency (ORE) of RSO extracted by different methods.

quality and the degree of purity of the oil. (Tasan et al., 2011). RSO extracted by solvent gave the highest FFA (2.41\%). This result agrees with Mohamed et al. (2007), who found that the acidity of RSO extracted by solvent was $2.24 \%$. While the FFA in other extracted methods amounted to $0.3,0.61$ and $0.71 \%$ for supercritical-CO2 $\left(\mathrm{SC}-\mathrm{CO}_{2}\right)$, hydraulic and screw-press respectively. Moreno et al. (2003) reported that lower FFA indicated that the quality of oil was better.

The sensitive methods are required to detect slight changes in unsaturation (Alexandri et al., 2017) such as measurement of iodine value (IV) and refractive index (RI) has been done in this study (Tab. 1). The quality of the oils is dependent on their chemical compositions, like the percentage of the degree of unsaturation. The IV of RSO extracted by $\mathrm{SC}-\mathrm{CO}_{2}$ was $97.76 \mathrm{~g}$ $100 \mathrm{~g}^{-1}$ and for oil extracted by hydraulic-press, it was

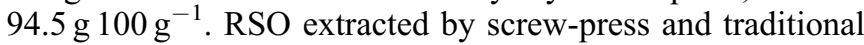
method (solvent) gave nearly the same value of IV (93.5 and

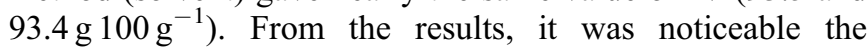
reduction in the IV in case of extraction oil by screw-press and solvent, this variation of unsaturation values may be due to the different extraction methods.

The RI of RSO was 1.4504, 1.4494, 1.4500 and 1.4562 for oil extracted by SC- $\mathrm{CO}_{2}$, hydraulic and screw-press as well as traditional method respectively. It was noticeable that there is no marked change in RI using different extraction methods. These results agreed with Mohamed et al. (2007), who found that RI of RSO was 1.4770 . The RI of oil could be a function of 
Table 2. Fatty acid composition of oil samples extracted by different methods.

\begin{tabular}{|c|c|c|c|c|}
\hline Fatty acids & \multicolumn{4}{|c|}{ Peak area $(\%)$} \\
\hline Myristic acid & $0.13 \pm 0.01$ & $0.13 \pm 0.01$ & $0.14 \pm 0.02$ & $0.13 \pm 0.01$ \\
\hline Palmitic acid & $20.52 \pm 0.87$ & $19.95 \pm 0.24$ & $19.93 \pm 0.71$ & $19.50 \pm 0.90$ \\
\hline Pamitoleic acid & $0.41 \pm 0.07$ & $0.53 \pm 0.05$ & $0.47 \pm 0.03$ & $0.43 \pm 0.01$ \\
\hline Margaric acid & $0.09 \pm 0.01$ & $0.10 \pm 0.04$ & $0.13 \pm 0.01$ & $0.13 \pm 0.02$ \\
\hline Linoleic acid & $39.91 \pm 1.65$ & $37.44 \pm 1.59$ & $36.95 \pm 1.35$ & $36.53 \pm 1.81$ \\
\hline Linoleic acids (conjugated) & $0.07 \pm 0.01$ & $1.44 \pm 0.27$ & $1.52 \pm 0.22$ & $1.41 \pm 0.08$ \\
\hline Linolenic acid & $1.20 \pm 0.17$ & $2.18 \pm 0.10$ & $2.30 \pm 0.31$ & $2.31 \pm 0.11$ \\
\hline Arachidic acid & $0.40 \pm 0.12$ & $0.37 \pm 0.02$ & $0.85 \pm 0.07$ & $0.81 \pm 0.14$ \\
\hline Behenic acid & $0.10 \pm 0.00$ & $0.21 \pm 0.03$ & $0.33 \pm 0.07$ & $0.30 \pm 0.07$ \\
\hline Lignoceric acid & ND & ND & ND & $0.13 \pm 0.01$ \\
\hline$\Sigma$ UFA & 70.97 & 69.24 & 68.68 & 68.75 \\
\hline$\Sigma \mathrm{UFA} / \Sigma \mathrm{SFA}$ & 2.66 & 2.45 & 2.4 & 2.54 \\
\hline Cox value & 4.67 & 4.25 & 4.73 & 4.69 \\
\hline
\end{tabular}

$\mathrm{ND}=$ not detected; SFA: saturated fatty acids; MUFA: monounsaturated fatty acids; PUFA: polyunsaturated fatty acids; $\Sigma$ UFA / $\Sigma$ SFA: unsaturated fatty acids to saturated fatty acids ratio.

its unsaturation and the higher the content of double bond, the greater the effect of reducing the refraction angle (Hasenhuettl, 2000)

Concerning specific gravity $\left(\mathrm{g} \mathrm{cm}^{3}\right)$, it was noticed that no remarkable changes in it by using different extraction methods.

The peroxide value (PV) is a useful indicator of the extent of oxidation of lipids, fats, and oils (Mohamed et al., 2018). The PV shows the degree of peroxidation and measures the primary oxidation products in the substance (Kouba and Mourot, 2011). The lowest value of PV was found in oil extracted by $\mathrm{SC}-\mathrm{CO}_{2}$ $\left(1.0 \mathrm{mEq} . \mathrm{O}_{2} \mathrm{~kg}^{-1}\right)$, while the highest PV in case of oil, extracted by solvent ( $4.57 \mathrm{mEq} . \mathrm{O}_{2} \mathrm{~kg}^{-1}$ ) (Tab. 1).

The saponification value (SV) of an oil or fat has an opposite correlation with molecular weight or chain length of its fatty acids (Abayeh et al., 1998; Ortiz et al., 2003). From the results in Table 1, it was found that the SV ranged from 190.04 until $193.91 \mathrm{mg} / \mathrm{g}$. The RSO extracted by screw-press gave the highest SV (193.91 mg/g). Mathur (2016) found that the value of SV $(200,190,196)$ resembles the normal values for vegetable oils. Nielsen (1989) and Kirk and Sawyer (1991) reported that high or low SV's of fats and oils are due to shorter or longer carbon chain lengths of the fatty acids.

\subsection{Fatty acid composition}

The fatty acid composition (FAC) determined by GC of RSO samples, illustrated in Table 2 and Figure 2, showed that the total content of unsaturated fatty acid (UFA) ranged from 68 to $70 \%$, from 26 to $28 \%$ for saturated fatty acids (SFA) and from 27 to $29 \%$ for monounsaturated fatty acid (MUFA). The ratio of UFA/SFA and Cox value in RSO extracted by $\mathrm{SC}-\mathrm{CO}_{2}$, hydraulic, screw-press (green methods) and conventional methods (solvent) were calculated to $2.66,2.45,2.4,2.54$ and $4.67,4.25,4.73,4.69$, respectively. Oleic and linoleic acids had the highest values of 29.38 and $39.91 \%$, respectively for RSO extracted by $\mathrm{SC}-\mathrm{CO}_{2}$. The FAC shown the high content in UFA, especially linoleic acid (ranged from 36.53 to $39.91 \%$ ), thus, is indicating the nutritional benefits of RSO. Linoleic acid has beneficial effects on blood lipids, lowering blood pressure and serum (Savage, 2001; Enujiugha and Akanbi, 2008). Among the UFA (Tab. 2), palmitoleic acid content was the lowest, nearly kept constant in RSO extracted by $\mathrm{SC}-\mathrm{CO}_{2}$, hydraulic, screw-press (green methods) and conventional methods (solvent), whereas palmitic acid was (SFA) $20.5 \%$ for oil extracted by $\mathrm{SC}-\mathrm{CO}_{2}, 19.9 \%$ for oil extracted by cold-press and $19.5 \%$ for oil extracted by solvent methods (Tab. 2). Minor identified FA's lauric, myrstic, arachidic, etc. These results were agreed with Al-Okbi et al. (2017). In addition, Al-Okbi et al. (2017) found that RSO was a unique balanced fatty acid ratio (S:M:P) refers to its possible direct human consumption.

\subsection{Tocopherol content of the RSO}

Tocopherols are the most important lipid-soluble natural antioxidants present in vegetable oils. The contents of total tocopherols in RSO extracted by green methods $\left(\mathrm{SC}-\mathrm{CO}_{2}\right.$, hydraulic and screw-press) as well as solvent are given in Table 3 and Figure 3 . The total tocopherol concentration increased in the case of RSO extracted by the $\mathrm{SC}-\mathrm{CO}_{2}$ method, followed by solvent extraction. While RSO extracted by hydraulic-press was higher total tocopherol than screw-press and the two extracted methods less than $\mathrm{SC}-\mathrm{CO}_{2}$ and solvent (Fig. 3). The optimum conditions yielded highly tocopherol concentration from RS were extracting by $\mathrm{SC}-\mathrm{CO}_{2}$, followed 


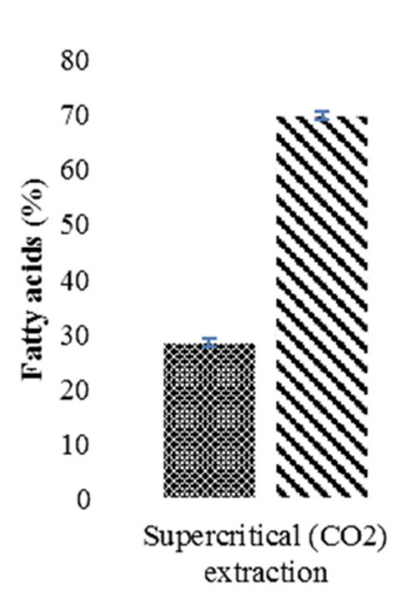

SFA vs UFA

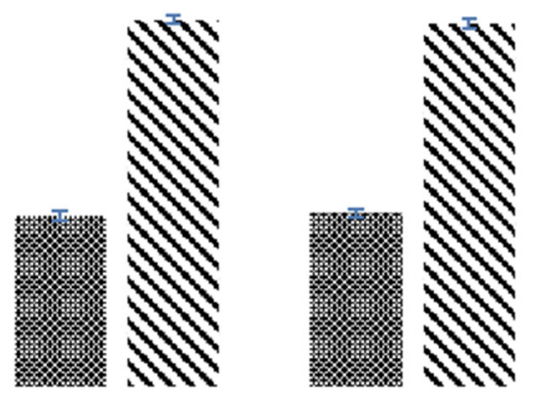

Hydraulic-press extraction
$*$ SFA $\quad$ UFA

Screw-press extraction

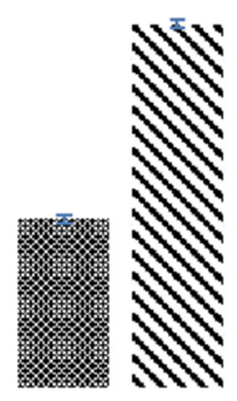

Solvent extraction

Extraction method

Fig. 2. SFA vs. UFA of RSO extracted by different methods.

Table 3. Effect of extraction methods on tocopherols content of RSO by HPLC.

\begin{tabular}{lllll}
\hline $\begin{array}{l}\text { Tocopherol fractions } \\
\text { content }(\mathrm{mg} / 100 \mathrm{~g} \text { oil) }\end{array}$ & \multicolumn{4}{c}{ Extraction methods } \\
\cline { 2 - 5 } & $\begin{array}{l}\text { Supercritical } \\
\left(\mathrm{CO}_{2}\right)\end{array}$ & $\begin{array}{l}\text { Hydraulic } \\
\text {-press }\end{array}$ & $\begin{array}{l}\text { Screw } \\
\text {-press }\end{array}$ & Solvent \\
\hline$\alpha$-tocopherol & $55.11^{\mathrm{a}}$ & $75.23^{\mathrm{c}}$ & $69.41^{\mathrm{bc}}$ & $65.57^{\mathrm{b}}$ \\
$\beta$-tocopherol & $\mathrm{ND}^{*}$ & $\mathrm{ND}$ & $\mathrm{ND}$ & $\mathrm{ND}$ \\
$\gamma$-tocopherol & $127.24^{\mathrm{b}}$ & $133.64^{\mathrm{b}}$ & $116.49^{\mathrm{a}}$ & $168.03^{\mathrm{c}}$ \\
$\delta$-tocopherol & $107.43^{\mathrm{d}}$ & $25.14^{\mathrm{a}}$ & $29.33^{\mathrm{bc}}$ & $33.75^{\mathrm{c}}$ \\
\hline
\end{tabular}

*ND $=$ not detected

Values in the rows with different letters $(a-d)$ are significantly different $(p<0.05)$. The same letters at the same column are not significant $(p<0.05)$.

by solvent then hydraulic-press and finally screw-press. Concerning the tocopherol composition of RSO, it was found that the highest and lowest amount of $\alpha$-tocopherol in case of hydraulic-press and $\mathrm{SC}-\mathrm{CO}_{2}$ extraction respectively (75.23 and $55.11 \mathrm{mg} 100 \mathrm{~g}^{-1}$ ). The highest amount of $\delta$-tocopherol $\left(107.43 \mathrm{mg} 100 \mathrm{~g}^{-1}\right)$ was found in oil extracted by the $\mathrm{SC}-\mathrm{CO}_{2}$ method. $\delta$-Tocopherol ranged from 25.14 to $33.75 \mathrm{mg} 100$ $\mathrm{gm}^{-1}$ oil in other three extracted methods. Concerning $\gamma$-tocopherol, solvent method gave the highest level followed by hydraulic-press, $\mathrm{SC}-\mathrm{CO}_{2}$ and then screw-press amounted to

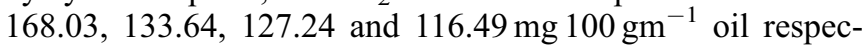
tively. $\gamma$-tocopherol could delay the oxidation of PUFA in oils. In addition, $\alpha$ - and $\gamma$-tocopherols have a special activity against free radicals and play an important role in the regulatory functions in the live cells (Chandra et al., 2002; Ricciarelli et al., 2002). Mohamed et al. (2007), they found that RSO extracted by solvent gave highest $\gamma$-tocopherol as antioxidant which agreed with our results.

\subsection{Total phenolic content (TPC)}

Results obtained in this study reveal that the level of total phenolic compounds (TPC) in RSO is considerable (Tab. 4).

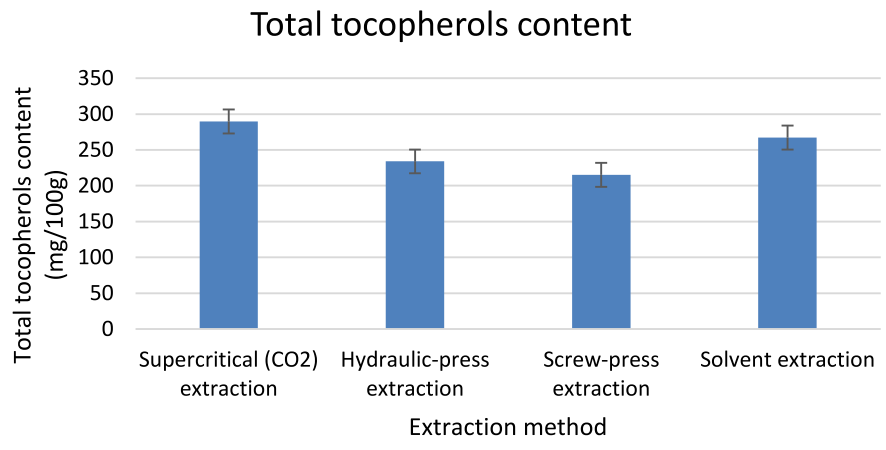

Fig. 3. Total tocopherols content of RSO extracted by different methods.

TPC of different RSO samples varied significantly $(p \leq 0.05)$ ranging from 13.74 to $22.18 \mathrm{mg} \mathrm{GAE}^{-1}$. The RSO prepared using $\mathrm{SC}-\mathrm{CO}_{2}$ extraction showed the highest total phenolic content $\left(22.18 \mathrm{mg} \mathrm{GAE} \mathrm{g}^{-1}\right)$, while the lowest was observed in case of oil extracted by screw-press $\left(13.74 \mathrm{mg} \mathrm{GAE} \mathrm{g}^{-1}\right)$, with a significant difference $(p \leq 0.05)$ when compared with other method extraction (Tab. 4). This study showed that RSO obtained using different extraction methods, had different total phenolic contents. There is a positive correlation between the total content of phenolic compounds and the antioxidant activity and over $95 \%$ of the antioxidant capacity is due to their phenolic components (Turkmen et al., 2007; Wang et al., 2017). Al-Okbi et al. (2017) found that RSO (extracted by screw press) was rich in bioactive constituents represented by total phenolics $\left(56.31 \mathrm{mgGAEg}^{-1}\right)$, and total tocopherol $(99.86 \mathrm{mg} / 100 \mathrm{~g})$ especially $\gamma$-tocopherol. Tsuda et al. (2003), found that a diet is rich in polyphenols could prevent obesity, or optimize the treatment of diabetes.

\subsection{DPPH radical scavenging activity}

The effect of green methods extraction on DPPH free radical scavenging activity of RSO was investigated (Tab. 4). 
Table 4. Total phenolic content, antioxidant activity and oxidative stability of RSO samples.

\begin{tabular}{|c|c|c|c|c|}
\hline Parameter & \multicolumn{4}{|c|}{ Extraction methods } \\
\hline Total phenolic content (mg of GAE/g) & $22.18 \pm 1.13^{\mathrm{a}}$ & $17.25 \pm 1.07^{\mathrm{b}}$ & $13.74 \pm 0.55^{\mathrm{c}}$ & $18.10 \pm 1.43^{b}$ \\
\hline DPPH radical-scavenging activity (\%) & $65.47 \pm 2.08^{\mathrm{a}}$ & $57.52 \pm 1.33^{\mathrm{b}}$ & $49.59 \pm 0.74^{\mathrm{c}}$ & $55.67 \pm 1.09^{\mathrm{b}}$ \\
\hline $\mathrm{EC}_{50}(\mathrm{mg} / \mathrm{mL})$ & $0.507^{\mathrm{d}}$ & $0.577^{\mathrm{c}}$ & $0.661^{\mathrm{a}}$ & $0.593^{\mathrm{b}}$ \\
\hline
\end{tabular}

$\mathrm{EC}_{50}$ value, the effective concentration at which the antioxidant activity was $50 \%$ and it was obtained by extrapolation from linear regression analysis; data are expressed as mean \pm standard deviation of three determinations.

Values in the rows with different letters $(\mathrm{a}-\mathrm{d})$ are significantly different $(p<0.05)$. The same letters at the same column are not significant $(p<0.05)$.

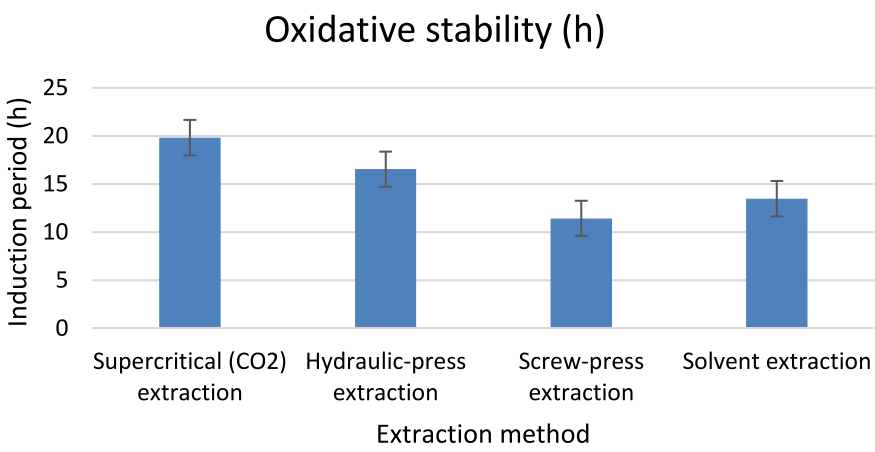

Fig. 4. Oxidative stability of RSO extracted by different methods.

The results showed that $\mathrm{SC}-\mathrm{CO}_{2}$ extraction method exhibited the highest DPPH scavenging activity (65.47). Oil extracted by hydraulic-press gave the higher DPPH (57.52) than solvent extraction (55.67). In addition, the $\mathrm{SC}-\mathrm{CO}_{2}$ extraction method had the highest scavenging activity; therefore, the lowest $\mathrm{EC}_{50}$. Statistical analysis revealed that the difference between the $\mathrm{SC}-\mathrm{CO}_{2}$ extraction method and the other extraction methods was significant $(p \leq 0.05)$. There is a positive correlation between the total content of phenolic compounds and the antioxidant activity (Turkmen et al., 2007; Wang et al., 2017).

\subsection{Oxidative stability index (OSI)}

According to the results of oxidative stability, it was found that the induction period (IP) of RSO's ranged from 12 to $20 \mathrm{~h}$ (Fig. 4), as measured by Rancimat at $110^{\circ} \mathrm{C}$. RSO oil extracted by $\mathrm{SC}-\mathrm{CO}_{2}$ had the highest IP $(20 \mathrm{~h})$, followed by oil extracted with hydraulic-press $(18 \mathrm{~h})$, then oil extracted by solvent and by screw-press. Thus, the stability of oil extracted by $\mathrm{SC}-\mathrm{CO}_{2}$, maybe due to contained appreciable amounts of more stable FA (omega-9). As well as, higher content of total phenolic, total tocopherol and $\gamma$-tocopherol, which is potent antioxidant and the best ratio of UFA/SFA, compared to other investigated oils. The oxidative stability of the oil is an important quality and safety parameter for their potential commercial applications and utilization in food and other commercial products, and it depends mostly on the FA composition as well as the potency and content of antioxidant of these oils (Yang et al., 2010). Al-Okbi et al. (2017), found that RSO extracted by screw press have IP $\left(24.9 \mathrm{~h}\right.$ at $\left.100^{\circ} \mathrm{C}\right)$.

\section{Conclusion}

The results show that the type of extraction methods is affecting the ratios and quality of major and minor components present in extracted RSO; subsequently, affecting the physicochemical properties on produced oil. From the results, it was found that green extraction methods were more efficient than the traditional one (solvent extraction). The results revealed that the $\mathrm{RSO}$ extracted by $\mathrm{SC}-\mathrm{CO}_{2}$ method gave the highest content of natural antioxidants (total tocopherol, TPC) as well as oxidative stability (DPPH, IP) than the other extraction methods. The cold-press extraction methods (hydraulic and screw-press) gave highest $\alpha$-tocopherol. Hydraulic-press extraction method gave the higher $\gamma$-tocopherol than SC-CO2. Cold press extraction methods gave higher oil yield than SC-CO2 and more economically than other methods. Cold-press involves no heat and/or chemicals and this is preferred by consumers concerned about natural and preserving the phytonutrients components of RSO that can be used as non-traditional edible oil.

\section{References}

Abayeh OJ, Aina EA, Okounghae CO. 1998. Oil content and oil quality characteristics of some Nigerian oils seeds. J Pure Appl Sci Tech 1: 17-23.

Abdel-Razek AG, El-Shami SM, El-Mallah MH, Hassanien MMM. 2011. Blending of virgin olive oil with less stable edible oils to strengthen their antioxidative potencies. Aust J Basic Appl Sci 5 (10): 312-318.

Abdel-Razek AG, Hassanein MMM, Rudzinska M, El-Mallah MH. 2017. Role of minor constituents and balanced fatty acids in upgrading the low stability of cooking oils blended with palm super olein. Asian J Sci Res 10: 150-159.

Akanda MJH, Sarker MZI, Ferdosh S, et al. 2012. Applications of supercritical fluid extraction (SFE) of palm oil and oil from natural sources. Molecules 17(2): 1764-1794.

Alexandri E, Ahmed R, Siddiqui H, Choudhary M, Tsiafoulis C, Gerothanassis I. 2017. High resolution NMR spectroscopy as a structural and analytical tool for unsaturated lipids in solution. Molecules 22(10): 1663.

Al-Okbi SY, Abdel-Razek AG, Mohammed SE, Ottai MES. 2017. Roselle seed as a potential new source of healthy edible oil. $J$ Biol Sci 17(6): 267-277.

Aniołowska M, Zahran H, Kita A. 2016. The effect of pan frying on thermooxidative stability of refined rapeseed oil and professional blend. J Food Sci Tech 53(1): 712-720. 
AOCS. 1997. Official Method Cd 12b-92, Oil stability index. Sampling and analysis of commercial fats and oils. Methods and recommended practices of the American Oil Chemists Society, 4th ed. USA: American Oil Chemists' Society.

Atta BM, Imaizumi K. 2002. Some characteristics of crude oil extracted from roselle (Hibiscus sabdariffa $\mathrm{L}$.) seeds cultivated in Egypt. J Oleo Sci 51(7): 457-461.

Bhatnagar AS, Krishna AG. 2013. Natural antioxidants of the Jaffna variety of Moringa Oleifera seed oil of Indian origin as compared to other vegetable oils. Grasas y Aceites 64(5): 537-545.

Chandra V, Jasti J, Kaur P, Betzel C, Srinivasan A, Singh TP. 2002. First structural evidence of a specific inhibition of phospholipase A2 by $\alpha$-tocopherol (vitamin E) and its implications in inflammation: Crystal structure of the complex formed between phospholipase A2 and $\alpha$-tocopherol at $1.8 \AA$ resolution. $J \mathrm{Mol}$ Biol 320(2): 215-222.

Cvjetko M, Jokic S, Lepojevic Z, Vidovic S, Maric B, Redovnikovic IR. 2012. Optimization of the supercritical $\mathrm{CO}_{2}$ extraction of oil from rapeseed using response surface methodology. Food Technol Biotechnol 50(2): 208.

Dhar P, Kar CS, Ojha D, Pandey SK, Mitra J. 2015. Chemistry, phytotechnology, pharmacology and nutraceutical functions of kenaf (Hibiscus cannabinus L.) and roselle (Hibiscus sabdariffa L.) seed oil: An overview. Ind Crops Prod 77: 323-332.

Donough CR, Cock J, Oberthür T, Indrasuara K, Gatot AR, Dolong T. 2013. Estimating oil content of commercially harvested oil palm fresh fruit bunches - A step towards increasing palm oil yields. In: Poster Presented at the PIPOC 2013 International Palm Oil Congress and Exhibition, pp. 19-21.

Elabd EMY, Zahran HA, Abdalla AM. 2017. A comparative study of the effects of three Moringa species on obesity-induced oxidative stress state in liver tissue. Int J Pharma Bio Sci 8: $572-584$.

Enujiugha VN, Akanbi CT. 2008. Quality evaluation of canned fermented oil bean seed slices during ambient storage. Afr J Food Sci 2(5): 054-059.

Fatemi SH, Hammond EG. 1980. Analysis of oleate, linoleate and linolenatehydroperoxides in oxidized ester mixtures. Lipids 15 (5): 379-385.

Firestone D. 2009. Official methods and recommended practices of the AOCS. Urbana, IL (USA): AOCS.

Gutfinger T. 1981. Polyphenols in olive oils. J Am Oil Chem Soc 58 (11): 966-968.

Hasenhuettl GL. 2000. Fats and fatty oils. In: Kirk-Othmer encyclopedia of chemical technology. pp 1-37. DOI: 10.1002/ 0471238961.

Hassanien MM, Abdel-Razek AG, Rudzińska M, Siger A, Ratusz, K Przybylski R. 2014. Phytochemical contents and oxidative stability of oils from non-traditional sources. Eur J Lipid Sci Technol 116(11): 1563-1571.

Ismail A, Ikram EHK, Nazri HSM. 2008. Roselle (Hibiscus sabdariffa L.) seeds-nutritional composition, protein quality and health benefits. Food 2(1): 1-16.

Kiralan M, Özkan G, Bayrak A, Ramadan MF. 2014. Physicochemical properties and stability of black cumin (Nigella sativa) seed oil as affected by different extraction methods. Ind Crops Prod 57: $52-58$.

Kirk S, Sawyer R. 1991. Pearson's composition and analysis of foods (No. Ed. 9). Harlow (UK): Longman Group Ltd.

Kouba M, Mourot J. 2011. A review of nutritional effects on fat composition of animal products with special emphasis on $\mathrm{n}-3$ polyunsaturated fatty acids. Biochimie 93(1): 13-17.
Lee YY, Park HM, Lee CK, et al. 2012. Comparing extraction methods for the determination of tocopherols and tocotrienols in seeds and germinating seeds of soybean transformed with OsHGGT. J Food Compost Anal 27(1): 70-80.

Mathur A. 2016. Extraction and studies on saponification values of some non edible seed oils from arid zone of Rajasthan. Int J Curr Eng Sci Res (IJESR) 3(3): 6-8.

Mohamed FAEF, Salama HH, El-Sayed SM, El-Sayed HS, Zahran HAH. 2018. Utilization of natural antimicrobial and antioxidant of Moringaoleifera leaves extract in manufacture of cream cheese. J Biol Sci 18(2): 92-106.

Mohamed R, Fernandez J, Pineda M, Aguilar M. 2007. Roselle (Hibiscus sabdariffa) seed oil is a rich source of $\gamma$-tocopherol. $J$ Food Sci 72(3): S207-S211.

Moreno AO, Dorantes L, Galíndez J, Guzmán RI. 2003. Effect of different extraction methods on fatty acids, volatile compounds, and physical and chemical properties of avocado (Persea americana Mill.) oil. J Agric Food Chem 51(8): 2216-2221.

Naeem MA, Abu Hashish HM, Zahran HA. 2017. Optimize the Roselle (Hibiscus sabdariffa L.) seeds oil extraction using screw press. Egypt J Nutr 32(4): 29-48.

Nair VDP, Kanfer I, Hoogmartens J. 2006. Determination of stigmasterol, $\beta$-sitosterol and stigmastanol in oral dosage forms using high performance liquid chromatography with evaporative light scattering detection.J Pharm Biomed Anal 41 (3): 731-737.

Nielsen SS. 1989. Introduction to the chemical analysis of foods (No.664.07 Su98c Ej. 1). New York: Chapman and Hall.

Nyam KL, Tan CP, Lai OM, Long K, Man YC. 2009. Physicochemical properties and bioactive compounds of selected seed oils. LWT-Food Sci Technol 42(8): 1396-1403.

Ortiz MA, Dorantes L, Galindez J, Guzman RI. 2003. Effect of different extraction methods on fatty acids, volatile compounds, and physical and chemical properties of avocado (Persea americana Mill.) oil. J Agric Food Chem 51: 2216-2222.

Pokorny J, Yanishlieva N, Gordon MH. 2001. Antioxidants in food: Practical applications. Boca Raton, Boston, New York, Washington D.C.: CRC press.

Ricciarelli R, Zingg JM, Azzi A. 2002. The 80th anniversary of vitamin E: Beyond its antioxidant properties. Biol Chem 383 (3-4): 457-465.

Rudzińska M, Hassanein MM, Abdel-Razek AG, Ratusz K, Siger A. 2016. Blends of rapeseed oil with black cumin and rice bran oils for increasing the oxidative stability. J Food Sci Technol 53(2): 1055-1062.

Rudzińska M, Hassanein MM, Abdel-Razek AG, Kmiecik D, Siger A, Ratusz K. 2018. Influence of composition on degradation during repeated deep-fat frying of binary and ternary blends of palm, sunflower and soybean oils with health-optimised saturated-to-unsaturated fatty acid ratios. Int J Food Sci Technol 53(4): 1021-1029.

Savage GP. 2001. Chemical composition of walnuts (Juglans regia L.) grown in New Zealand. Plant Foods Hum Nutr 56(1): 75-82.

Soto C, Chamy R, Zuniga ME. 2007. Enzymatic hydrolysis and pressing conditions effect on borage oil extraction by cold pressing. Food Chem 102(3): 834-840.

Tasan M, Gecgel U, Demirci M. 2011. Comparison of geometrical isomerization of unsaturated fatty acids in selected commercially refined oils. Grasas y Aceites 62(3): 284-289.

Tsuda T, Horio F, Uchida K, Aoki H, Osawa T. 2003. Dietary cyanidin 3-O- $\beta$-D-glucoside-rich purple corn color prevents obesity and ameliorates hyperglycemia in mice. J Nutr 133(7): 2125-2130. 
Turkmen N, Velioglu YS, Sari F, Polat G. 2007. Effect of extraction conditions on measured total polyphenol contents and antioxidant and antibacterial activities of black tea. Molecules 12(3): 484-496.

Wang S, Chu Z, Ren M, Jia R, Zhao C, Fei D, Wang Y. 2017. Identification of anthocyanin composition and functional analysis of an anthocyanin activator in solanumnigrum fruits. Molecules 22(6): 876.

Wong YH, Tan CP, Long K, Nyam KL. 2016. In vitro simulated digestion on the biostability of Hibiscus cannabinus L. seed extract. Czech J Food Sci 32(2): 177-181.
Yang MY, Peng CH, Chan KC, Yang YS, Huang CN, Wang CJ. 2010. The hypolipidemic effect of Hibiscus sabdariffa polyphenols via inhibiting lipogenesis and promoting hepatic lipid clearance. $J$ Agric Food Chem 58(2): 850-859.

Yokota J, Takuma, D, Hamada A, et al. 2006. Scavenging of reactive oxygen species by Eriobotrya japonica seed extract. Biol Pharm Bull 29(3): 467-471.

Zuniga ME, Soto C, Mora A, Chamy R, Lema JM. 2003. Enzymic pre-treatment of Guevina avellanamol oil extraction by pressing. Process Biochem 39(1): 51-57.

Cite this article as: Naeem MA, Zahran HA, Hassanein MMM. 2019. Evaluation of green extraction methods on the chemical and nutritional aspects of roselle seed (Hibiscus sabdariffa L.) oil. OCL 26: 33. 